International Journal of Agriculture, Environment and Bioresearch

Vol. 5, No. 02; 2020

ISSN: $2456-8643$

\title{
FLORISTIC AND FAUNA INVENTORY OF THE ECOLOGICAL SITE OF THE OUESSE CROCODILE POND FOR ECO-TOURISM DEVELOPMENT PROPOSALS IN THE MUNICIPALITY OF SAVALOU-BENIN
}

\author{
Louis DJEGBATE ${ }^{1}$, Alain ZINGONGO ${ }^{2}$, Norbert AGOINON ${ }^{3}$, Jose Edgard GNELE ${ }^{3}$, Odile GUEDEGBE \\ DOSSOU $^{1}$ \\ ${ }^{1}$ Laboratory of Regional Planning, Environment and Sustainable Development (LATEDD), Department of \\ Geography and Regional Planning (DGAT), University of Abomey-Calavi (Benin) \\ ${ }^{2}$ University of Quebec in Chicoutimi (Canada) \\ ${ }^{3}$ Laboratory of Biogeography and Environmental Expertise (LABEE), Department of Geography and Regional \\ Planning (DGAT), University of Abomey-Calavi (Benin)
}

https://doi.org/10.35410/IJAEB.2020.5497

\begin{abstract}
The main objective of this study is to inventory the fauna and flora of the crocodile pond in order to come up with development proposals for ecological and ecotourism restoration of the ecosystem. To achieve this objective, two field phases were carried out respectively in April and October 2018 for one week at each descent. This provision made it possible to take into account the temporal and/or seasonal dimension of the dynamics of the biological resources in place. The wildlife inventory was carried out on the basis of direct and indirect observations during the day and at night, supplemented by trapping captures. Night and day mounts were made. Crocodiles, endemic to the pond, have been the subject of an in-depth study of their habitat and ecology in the environment. The floristic inventory was carried out through vegetation surveys both inside and outside plots. Semi-structured individual and group interviews were conducted with local populations, authorities and local government officials in order to take into account the interests of the various stakeholders in the development proposals. A total of nine (09) mammal species, twenty (20) bird species, one (01) fish species, one (01) crustacean species and five (05) amphibian species were inventoried on all three (03) pools during the field phase of this study. The vegetation of the ponds and its associated areas include about thirty woody species divided into sixteen (16) families. The most dominant families are those of Moraceae (04 species) including the genus Ficus, followed by Mimosaceae, Sapindaceae represented by three species each. The other families are at most represented by two species. The ecological restoration of the crocodile pond must involve enriching the food chain and maintaining it through periodic stocking with catfish and tilapia. Two platforms are to be built on the pond and banks using locally collected stone paving stones to improve crocodile sightings by tourists. In the same way, an internal ecotourism tour will be planned and visit contents developed.
\end{abstract}

Keywords: Fauna, flora, development, écotourism, Savalou.

\section{INTRODUCTION}


The Ouèssè crocodile pond is one of the flagship tourist sites of the commune of Savalou with national and international renown. National ecological heritage, this highly sacred site in the past is distinguished by a permanent presence of crocodiles and lush vegetation in an equatorial climate. This study aims to make a flora and fauna inventory of the ecological site of the crocodile pond of Ouèssè / Savalou and its related riches in order to make it a reference ecotourism site in the Hills department in general and in the commune of Savalou in particular.

To reach conclusive results, this study was carried out in two stages across the two seasons of the year in order to allow us to take into account the spatio-temporal dynamics of the biological resources present. The results will allow us to launch the promotion of scientific tourism and to offer tourist circuits on the themes of flora and fauna for the development of ecotourism activities in order to support the employability of young people.

\subsection{Framework of the study}

The study took place in the commune of Savalou. This commune is located in the south-west of the Collines department and covers an area of $2,674 \mathrm{~km}^{2}$ (INSAE, 2013). It is between $7^{\circ} 35$ and $8^{\circ} 13$ North latitude on the one hand and $1^{\circ} 30$ and $2^{\circ} 6$ East longitude on the other hand (Figure 1). It shares its borders with the municipalities of Dassa-Zoumè and Glazoué in the East; from Djidja to the South, from Bantè to the North and the Republic of Togo.

The Ouèssè crocodile pond in the commune of Savalou is a tourist site with a national reputation of $17,852.8 \mathrm{~m} 2$, with a perimeter of 650.36 meters. The site will be found at the entrance to the Dèhouinzoun forest which is a sacred forest of approximately 44 hectares in area. It is characterized by various plant and animal species which are of ecological and spiritual interest likely to elucidate scientific and tourist curiosities. The sacred pond with crocodiles is limited to the North by the Déhouinzou forest, to the South by the agglomeration of Ouèssè, to the east by the chain of hills of Savalou and the village of Doïssa and to the west by the villages of Aglamidjodji and Agonmè. 


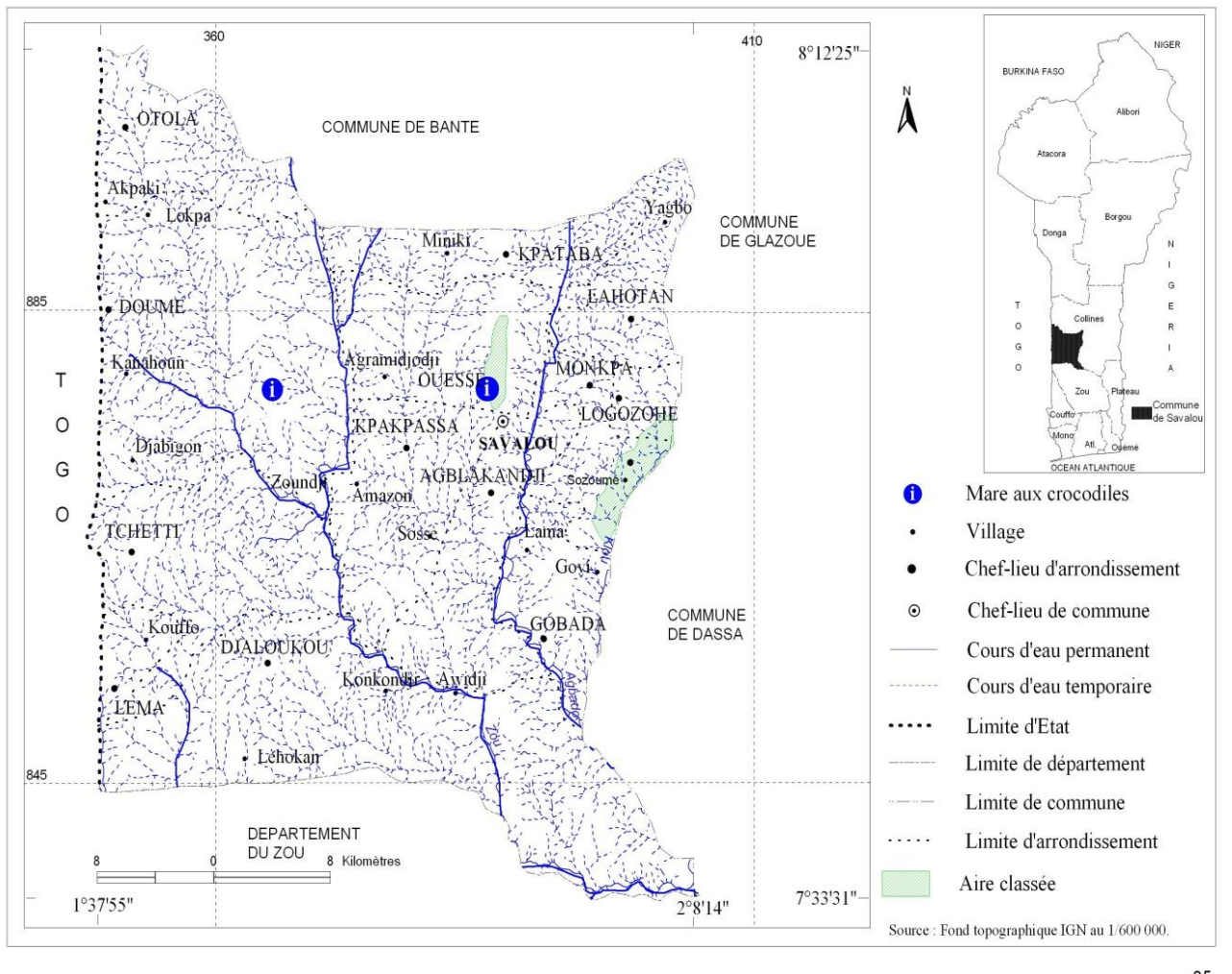

Figure1: Location of the town of Savalou and the crocodile ponds

\section{MATERIALS AND METHODS}

To take into account the dynamics of the ecosystem and the biological resources in place, the field phase of this study was organized in two seasons: the first in March and the second in October 2019. The fundamental difference between these two periods is that the month of March corresponds to the critical phase of the dry season while the month of October is much wetter and corresponds more or less to the period of high water.

\subsection{Wildlife inventory}

\subsubsection{Material}

The inventory and enumeration of fauna was carried out using the following equipment:

Two pairs of binoculars (20x15 magnification) to observe, assess and identify or even count from a distance, an animal, a herd or a colony;

A telescope (40x20 magnification), it played almost the same role with the only difference that it was mainly used for the identification of birds; 
A pair of infrared binoculars for night hides (20x20 magnification);

Variable mesh and size nets for sampling fish fauna;

A 20 meter long fishing seine with a mesh of $4 \mathrm{~mm}$ knots to knots and fishing rods to complete the results of catching dip nets;

Mouse traps for trapping small rodents;

A digital camera.

\subsubsection{Methods}

Using the linear transect method, animal densities can be estimated by direct observation (visual contact with the animal), or even indirect (counting droppings, nests, etc.). This estimate is based on the observation that the probability of detecting an animal, a nest or a droppings decreases with the distance (perpendicular) to the transect. The estimation of a density along a linear transect is given by the following formula (Buckland et al. 1993):

$\operatorname{Dc}=\mathrm{n} / 2 \operatorname{lv}(\mathrm{x}) \operatorname{avec} \mathrm{v}(\mathrm{x})=\int \mathrm{g}(\mathrm{x}) \cdot \mathrm{dx}$

Where Dc is the density, $\mathrm{n}$ is the number of observations made, $\mathrm{L}$ is the length of the line, $\mathrm{g}(\mathrm{x})$ is the detection function, $w$ is the width of the line and $y(x)$ is the effective width of transect, i.e. the integral of $\mathrm{g}(\mathrm{x})$ over the width of the layon. This function characterizes the evolution of the probability of detection as a function of the distance perpendicular to the axis of the line. This method was combined with direct and indirect observations on the site and its surroundings as well as summary surveys carried out with local residents.

Direct observations: these are animal observations carried out visually during day and / or night lookouts, with or without the help of specific equipment. Faced with the narrowness of the study area, several strategic observation points were defined giving access to an overview of the site. To complete these observations made statically, the site was visited on foot and randomly at regular frequency.

Indirect observations: these are signs of the presence of animals thanks to their various traces left on the site (footprints, passageways, droppings, burrows, shells).

Interviews: these are informal and / or semi-structured interviews carried out with the populations of Ouèssè as well as hunters and notables of the locality.

\section{2) Floristic inventory}


The floristic inventory was carried out by means of vegetation surveys in three (03) $900 \mathrm{~m} 2$ plots. The different strata were distinguished and the abundance-dominance and then the overlap were assessed. Overall, three levels have been distinguished:

- The herbaceous stratum or low stratum;

- The shrub layer or intermediate layer and,

- The tree or high stratum.

The large trees not found in the vicinity of the site have been inventoried. Herbaria have been made and the identifications of plant species have been confirmed in the national herbarium and the scientific and vulgar names confirmed in the flora of Benin.

\subsection{Processing and analysis of results}

Data processing is to estimate the relationship between the distance to an animal's walking line and its probability of being detected, i.e. the detection function $\mathrm{g}(\mathrm{x})$. The number of observations necessary for modeling the probability of detection is between

25 and 40 minimum (Buckland et al. 1993). Since direct observations of animals are very infrequent in humid forests, the total length of transect to be covered is very significant. Consequently, the estimation of an animal density in the humid forest can only be envisaged indirectly (estimation of the density of droppings or nests). Indeed, animal densities can theoretically be obtained by estimating conversion factors, that is to say the rate of production and degradation of droppings or nests. The resulting relationship is as follows: $\mathrm{D}=\mathrm{Dc} \times \mathrm{Td} / \mathrm{Tp}$ where D represents the animal density, Dc the density of droppings or nests on the transect, Td the average rate of degradation of droppings or nests, Tp the average rate of production of droppings or nests (White, Edwards, 2001). Microsoft Word software is used for word processing and Excel spreadsheet for tables and calculations of frequency and abundance of animals.

\section{RESULTS}

\subsection{History of the Ouèssè crocodile pond}

The story of the Ouèssè crocodile pond is quite variable from one person to another like most stories from villages in Benin and Africa. However, there is still a common thread that connects the different versions of the story. Thus, after the various cross-checks, it emerges in all versions that it is a pond recognized unanimously as sacred. A long time ago in the village of Ouèssè, the first inhabitants always had difficulty in obtaining water for various needs during the dry season due to its scarcity. Thus, around the 1950s, the dry season had been very trying since all the local water points had dried up. The entire population in distress imagined and felt the end of the world coming. Traditional leaders and dignitaries then did everything in their power without success. One day, a traditional chief desperately evolving in nature with followers had a revelation and stopped abruptly then asked his companions to dig under his feet saying: "here, there is a deity who reveals that on him, he there is water and yet nobody has known it until then 
". Thus, the companions began to dig and less than five (05) meters, they fell on a sheet of water and it was the great surprise and a popular jubilation in Ouèssè. "Todjitché" is the name of the deity who saved the people then from this water crisis. The name "Todjitché" means nothing other than the literal translation of the expression "I have water over me" in the local Mahi dialect. The populations believed then that this pond which had just been dug, there was a supernatural being who deserved respect, obedience, adoration and offerings. It was therefore that this pond was considered sacred. Later, crocodiles found refuge there and became natural witnesses to the presence of this deity.

\subsection{Description of the crocodile pond site}

The Ouèssè crocodile pond is a complex of three (03) small ponds of varying importance. These can be described as follows:

Todjitché or pond 1: with a total area of $1000 \mathrm{~m} 2$ and summarily fenced, it reduces to around twenty $\mathrm{m} 2$ of water surface in the dry season. The pond at an average depth of $70 \mathrm{~cm}$ at low water. On the other hand, during the flood, it extends over an area of approximately $300 \mathrm{~m} 2 \mathrm{with}$ a depth that reaches 1.5 or even 2 meters in places. The thermal amplitude is large and very variable between day and night. In fact, temperatures are high throughout the year with minimums between 23 and $24^{\circ} \mathrm{C}$ and maximums which vary from 35 to $36^{\circ} \mathrm{C}$. The soil is sandy-loamy. It is the most frequented pond by the inhabitants of Ouèssè and tourists because of the permanent presence of water and the emblematic animals of the site. Indeed, the quality of this water is highly appreciated by residents for domestic needs because, it would foam better compared to the water of existing hydraulic works. As a result, "Todjitché" seems better maintained than the other ponds. The plant cover is relatively large. There are the largest trees in the entire site. This pond was fenced in concrete topped with wire mesh thanks to financial and technical support from the Beninese Environment Agency (ABE) in 2003 and another support from the municipal budget reinforced by funding from the Embassy of France in Benin in 20092010 with the completion of the fence of the facade in local building materials for an integration into the environment of the pond. The site has been enlarged and entirely fenced in posts reinforced with barbed wire and reinforced by local species with rapid growth. At the end of this work, the natural flow corridors of the runoff water were preserved. It is the most important pond in terms of culture, history and biological resources.

Than or pond 2: with a total area of around $70 \mathrm{~m} 2$, it boils down at the end of the dry season to a water hole of around $1 \mathrm{~m} 2$ of more or less deep surface. The plant cover is relatively dense and closed. Outside the surrounding food crop fields, the "than" pond is very little frequented by local residents since it is a little more sacred, dangerous and is said to house more giant crocodiles with heads garnished with cowrie shells dotted with bird feathers.

Pool 3: with a total area of around $20 \mathrm{~m} 2$, it dries up entirely in the dry season. The plant cover is low.

\section{3) Vegetation of the Ouèssè crocodile pond}


The vegetation of the mares and related areas complex forming the study site includes about thirty woody species divided into sixteen (16) families. The most dominant families are those of Moraceae (04 species) including the genus Ficus, followed by Mimosaceae, then Sapindaceae each represented by three species. The other families are represented by at most two species.

From the site-specific richness point of view, the three zones explored present a very indistinct range of species. The Todjiche pool shares with its related area 11 species, or $65 \%$ of its specific richness. These common species, however, represent $50 \%$ of the specific richness of its related area.

Most of these woody trees are interwoven with both herbaceous and woody lianas: Abrus precatorus (Fabaceae), Dioscorea sp. (Dioscoreaceae), Luffa aegyptiaca (Cururbitatceae), Opilia celtidifolia (Opiliaceae), Paulinia pinata (Sapindaceae), Tacazzea apiculata (Asclepiadaceae).

The undergrowth consists essentially of species typical of closed environments such as Anchomanes difformis (Araceae), Cyphostemma sp. (Vitaceae), Aneilema sp. (Commeliananceae), Chassaia kolly (Rubiaceae), Commelina erecta (Commeliananceae), bushes: Flueggea virosa (Euphorbiaceae), Hoslundia opposita (Lamiaceae). There are also some ordinary species and some grasses that reflect the disturbance to which the site as a whole is subject. This tendency towards site degradation is expressed mainly through the presence of Sida acuta (Malvaceae), Pupalia lappaceae (Amaranthaceae), Thalinum triangulare (Portulacaceae), Croton lobatus (Euphorbiaceae), Chromoleana odorata (Asteraceae), Hyptis suaveolens (Lamiaceae) maximum and Andropogon gayanus (Poeceae).

Indeed, it has been observed that very few species of trees admit young shoots in their surroundings. Apart from Elaeis guineensis (Arecaceae), only Albizia lebbeck (Mimosaceae) is represented in all the strata. Species such as Ceiba pentandra (Bombacaceae) and Lannea barteri (Anacardiaceae) present in the tree and shrub strata, show no regeneration. present exclusively in the shrub layer are: Voacanga africana (Apocynaceae), Morinda lucida (Rubiaceae), Ficus on (Moraceae), Vernonia amygdalina (Asteraceae), Bridelia ferruginea (Euphorbiaceae), Ficus sycomorus (Moraceae), Alchornea cordifolia) Terminalia avicenoides (Combretaceae) and those represented only in the tree layer: Anogeissus leiocarpus (Combretaceae), Ficus platyfilla (Moraceae) show no regeneration.

This state of affairs is only the result of a sustained anthropogenic disturbance which has interrupted the regeneration process of these species for several decades.

Other species not represented in the shrub layer or in the tree layer are found in the lower layer and constitute regeneration. These are: Azadirachta indica (Meliaceae), Rauvolfia vomittoria (Apocynaceae), Daniella oliveri (Cesalpiniaceae), Parkia bigloboza (Mimosaceae), Ficus glumosa (Moraceae), Leucaniodiscus cupaniö̈des (Sapindaceae), Clerodendaceae capitum) (Anonaceae). 
These species have been recorded at the edge of fields and fallows where sustained anthropogenic pressure is directed against their growth and development for the benefit of food crops.

\section{4) Fauna richness of the Ouèssè crocodile pond}

Throughout the study area, 41 animal species belonging to 32 families were observed. These are distributed as follows: 09 species of mammals, i.e. $22 \%$ of the animal species richness of the pond, 20 species of birds (49\%), 01 species of fish (3\%), 01 species of crustaceans (2\%), 05 species of amphibians (12\%), 05 species of reptiles (12\%), Figure 2.

This analysis shows that the fauna of the site is mainly avian (49\%). It is a significant indicator around which ecotourism can develop on said site. That is to say that only the songs, the flights, the categories of birds, immerse the tourist in a leisure activity and make him want to come back or bring in others. The mammals assessed at (22\%) are generally made up of rodents such as: the whale, the giant rat, the palm rats, the squirrels, the dormouse and many other species which attract the attention of the visitor. Reptiles and amphibians (12\%) represent the emblematic species of the site. They are essentially made up of crocodiles, animals that are visited on the site, monitor lizards, snakes, toads, frogs whose leaps attract the attention of the visitor whose concern is the observation of the natural aspect of natural resources . Crustaceans and fish are made up of crabs and catfish which are generally used to feed crocodiles.

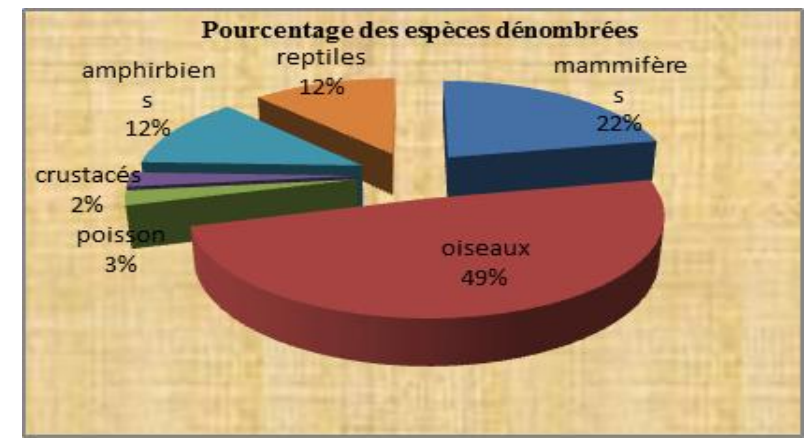

Figure 2: Schematic representation of inventoried wildlife wealth

\section{Mammals}

The species of mammals encountered on the site of the "caiman pond" are: Thryonomis swinderanus, crycetomis gambianus, lepus sp, lemnyscomis striatus, beige mouse, grasscutter, duiker and cercopithecus tantalus.

The disturbances caused by the local populations on the site unfortunately made it possible to observe only one species of small rodents. The other species inventoried are based on the testimonies of local hunters as well as on the observation of signs of presence. None of the mammals listed has endangered status. The reported presence of tantalum vervet and a duiker is 
interesting, however, and gives us something to dig into. Since habitat plays a strategic role for animals, it could not be otherwise with the rural activities that are practiced around the pond.

Birds

In total, twenty species of birds have been identified. The most abundant species are Ploceus cuculatus which are gregarious manners with groups of more than ten individuals.

With binoculars, they are easily observable species at least during the dry season. The majority of the birds surveyed are relatively common with the exception of Estrilda melpoda which is more or less rare. According to initial observations, the majority of the birds surveyed do not nest on the spot. Crocodile ponds would therefore be for them essentially feeding and drinking areas.

Table 1: Different species of birds listed on the site.

\begin{tabular}{|c|c|c|c|}
\hline $\mathrm{N}^{\circ}$ & Espèces & Nombre d'espèces & $\begin{array}{l}\mathrm{N}^{\circ} \text { de la Mare } \\
\text { d'observation }\end{array}$ \\
\hline 1 & glaucidium reported & 2 & 2 \\
\hline 2 & Tockus poweriae & 1 & 2 \\
\hline 3 & Picnonotus beard & Dizaine & 2 \\
\hline 4 & Plocens cuculatus & Centaine & 2 \\
\hline 5 & Lagonospicta senegala & 10 & 2 \\
\hline 6 & Cmnyris $s p$ & 3 & 2 \\
\hline 7 & Turtle senegalens $U$ & 1 & 2 \\
\hline 8 & Centropns senegalens $U$ & 1 & 2 \\
\hline 9 & Eetrilda melpoda & 2 & 2 \\
\hline 10 & African turtle & 1 & 2 \\
\hline 11 & Francollnus bioaloaratus & 8 & 2 \\
\hline 12 & Cattle Egret & 20 & 2 \\
\hline 13 & Bntorides fluted & 1 & 1 \\
\hline 14 & Hedydipna collar! & 1 & 2 \\
\hline 15 & Tchagra senegala & 1 & 2 \\
\hline 16 & Tockus poweriae & 1 & 1 \\
\hline 17 & Sylvia arnndinacens & 3 & 2 \\
\hline
\end{tabular}




\begin{tabular}{|llll|}
\hline 18 & green Terpsiphone & 2 & 1 \\
19 & Oiseau à bec jaune & 1 & 1 \\
20 & CEYX picture & 1 & 1 \\
\hline
\end{tabular}

Source: Fieldwork, 2009 and 2019

\section{Fish}

Given the physico-chemical parameters of pond water in the dry season $(\mathrm{pH}=4.7$; turbidity less than $30 \mathrm{~cm}$ ), it was obvious that the ichthyan diversity would be affected. Unsurprisingly, only a silurid, Clarias gariepinus survives in these harsh conditions for fish in the dry season (CREDI ONG, 2009, p. 12).

On the other hand, in the rainy season, this ichthyan diversity widens to killies (small fish) which have annual life cycles for the most part. These are mainly fish of the genus Epiplatys and Aplocheilichthys sp which abound during the rainy season at the level of the three ponds. The killies are not of food interest because they are very small. They are considered ornamental fish that can attract the attention of tourists.

Table 2: Different species of fish identified

\begin{tabular}{|lllll|}
\hline Espèces & $\begin{array}{l}\text { Noms } \\
\text { vulgaires }\end{array}$ & Nombre & Mare & Observations \\
$\begin{array}{l}\text { Clarias } \\
\text { gariepinus }\end{array}$ & Silure noir & 01 & 1 & Pêché à la ligne (taille $45 \mathrm{~cm}$ ) \\
$\begin{array}{l}\text { Epiplatys } \\
\text { grahami }\end{array}$ & Killies & $\begin{array}{l}\text { Très } \\
\text { abondant }\end{array}$ & $1-2-3$ & $\begin{array}{l}\text { Absentes pendant la saison } \\
\text { sèche }\end{array}$ \\
Aplocheilichys sp & Killies & $\begin{array}{l}\text { Très } \\
\text { abondant }\end{array}$ & $1-2-3$ & \\
\hline
\end{tabular}

Source: (CREDI ONG, 2009), fieldwork, 2019

\section{Reptile}

The actual presence of a relic population of the Nile crocodile could be demonstrated without great difficulty in the "Todjitché" and "Than" ponds, both in the dry season and during the rainy season. Their number is estimated at around fifteen in the dry season. In contrast, during the 
rainy season, it was not possible to estimate the abundance of crocodiles mainly due to the very high water level during this period in the various ponds.

As a result, one could conclude that the flood period is not the ideal season for crocodile watching. However, the developments underway on the banks could improve this state of affairs.

Another remarkable large reptile is the Nile monitor lizard, for which ponds provide comfortable shelter and abundant food (amphibians, crustaceans, small rodents) has been observed. The presence of juveniles of the species around the ponds suggests that it breeds there regularly. The abundance of this reptile during the rainy season is quite remarkable due to the relatively more contacts obtained during this period.

Compared to snakes, only a forest cobra was observed in the hollow of a tree near the "Todjitché" pond during the dry season. A large predator of rodents, its presence around the pond is certainly linked to the presence of large populations of squirrels and small rodents. During the rainy season, a striking viper was caught between the "Todjitché" and "Than" pools, which suggests that populations of vipers are found there.

Table 3: Different species of reptiles identified

\begin{tabular}{|lllll|}
\hline Espèces & Noms vulgaires & Nombre & Mare & Observations \\
$\begin{array}{l}\text { Crocodilus } \\
\text { niloticus }\end{array}$ & Crocodiles du Nil & Vingtaine & $1-2$ & Dans leur terrier \\
Varanus niloticus & Varan & 06 & $1-2$ & Jeunes et adultes \\
$\begin{array}{l}\text { Scinque } \\
\text { Agama agama }\end{array}$ & Caméléon & Nombreux & 02 & \\
$\begin{array}{l}\text { Naja } \\
\text { melanoleuca }\end{array}$ & Naja & 01 & 01 & Adultes $(1,50 \mathrm{~m})$ \\
Python sebae & Python & & 02 & $\begin{array}{l}\text { Témoignages } \\
\text { riverains }\end{array}$ \\
Viperinae & Vipère & 01 & Entre $1 \& 2$ & Capturés \\
\hline
\end{tabular}

Source: CREDI ONG, 2009, fieldwork, 2019

\section{Amphibians}

In total, six (06) species of amphibians are listed around the ponds. The majority of the observations were made at night, indicating the nocturnal manners of the majority of them. Only Xenopus sp. Lives permanently in water. 
The other species are much more terrestrial and live on the banks of the ponds. During the day, the latter live hidden in the litter of the undergrowth or in burrows dug around the ponds.

Table 4: Different species of amphibians identified

\begin{tabular}{|lcl|}
\hline Species & Mare & Observations \\
Xenopus sp & 02 & Adults \\
Bufo regularis & 02 & \\
Rana sp 1 & 02 & Riverbank / in reproduction \\
Haplobatrachus occipitalis & $1 \& 2$ & Big size \\
Frog sp 2 & 02 & Two white stripes \\
\hline
\end{tabular}

Source: (CREDI NGO, 2009), fieldwork, 2019

\section{Shellfish}

Only one species of crustacean has been observed both during the dry season and during the flood period. It is a crab infused with wetlands but with essentially terrestrial habits: Cardiosoma Armatum still called giant crab. It is active at night and a few times a day. It is abundant around the two main marshes and its presence is easily detectable by the many characteristic terriers it digs for shelter.

Table 5: Different species of crustaceans identified

\begin{tabular}{|clll|}
\hline \multicolumn{1}{|c|}{ Espèces } & Nombre & Mare & Observations \\
$\begin{array}{l}\text { Cardiosoma } \\
\text { armatum }\end{array}$ & Nombreux & 1 et 2 & Creuse des terriers \\
\hline
\end{tabular}

Source: fieldwork, 2019

\subsection{Floristic richness of the site for ecotourism}

The vegetation of the pond and related areas forming the study site includes around thirty woody species distributed among 16 families. The most dominant families are those of Moraceae (4 species) including the genus Ficus, followed by Mimosaceae, then Sapindaceae each represented by three species (Figure 3). The other families are represented by at most two species. 


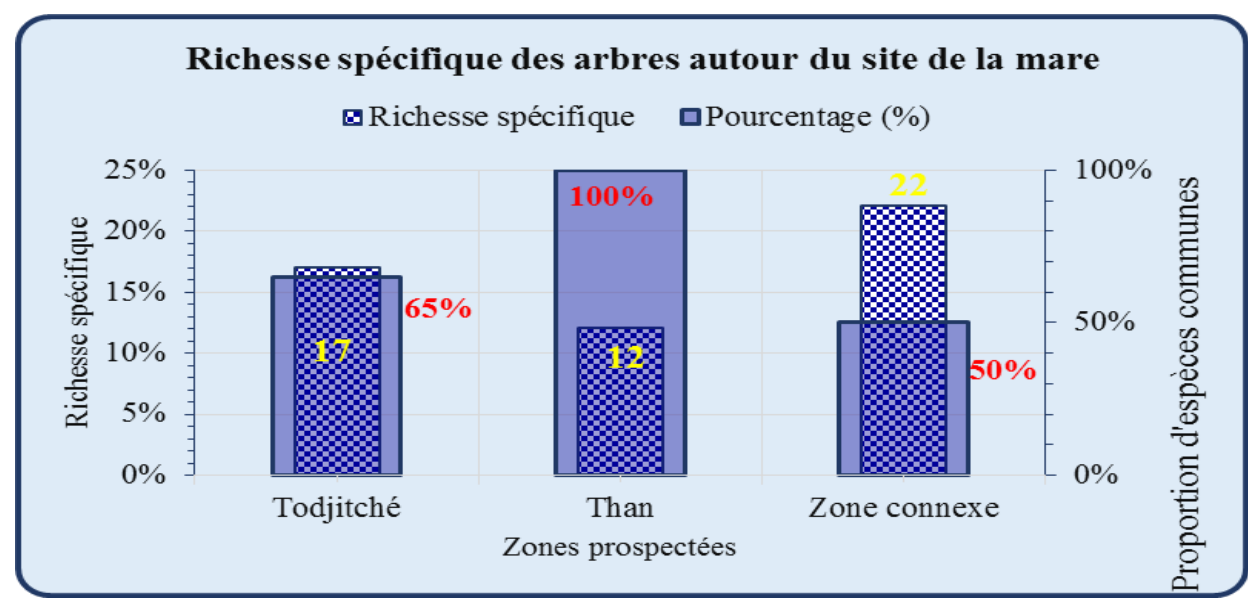

Figure 3: Specific richness of the trees around the crocodile pond site

From the site specific richness point of view, the three zones explored present a very indistinct range of species. The Todjiche pool shares with its related area eleven (11) species, or $65 \%$ of its specific richness. These common species, however, represent $50 \%$ of the specific richness of its related area.

In view of the floristic and spatial affinity of these two environments (Mare Todjitché and related area), it would be preferable for this related area to be added to the pond to constitute a functional plant community maintained in a state of nature for the ecotourism promotion of the site. . This merger is all the more necessary to secure a local microclimate and a habitat favorable for the well-being of existing fauna.

At the Than pond, only twelve (12) woody species have been inventoried, all of which are also found in the Todjitché pond and its related area.

Ultimately, the vegetation of the two crocodile pools and their related areas forms a continuum that cannot be dissociated at the risk of weakening the dynamics and the functioning of the ecosystem to which fauna, in particular crocodiles, are subservient.

The flora of the mare complex and its various related areas dominated by species such as: Ceiba petandra, Anogeissus leiocarpus, Albizia lebbeck, Elaeis guineensis and Lannea barteri uniformly widespread, have given a particular physiognomy more or less dense in the tree layer. Its undergrowth is practically devoid of savannah grasses which gives it the appearance of a dense moist formation.

Most of these woody trees are interwoven with both herbaceous and woody vines: Abrus precatorus (Fabaceae), Dioscorea sp. (Dioscoreaceae), Luffa aegyptiaca (Cucurbitatceae), Opilia celtidifolia (Opiliaceae), Paulinia pinata (Sapindaceae), Tacazzea apiculata (Asclepiadaceae). The undergrowth consists mainly of species typical of closed environments such as: Anchomanes difformis (Arostem) sp. (Vitaceae), Aneilema sp. (Commelinanceae), Chassalia 
kolly (Rubiaceae), Commelina erecta (Commelinanceae), bushes: Flueggea virosa (Euphorbiaceae), Hoslundia opposita (Lamiaceae). There are also some ruderal species and some grasses that reflect the disturbance to which the site as a whole is subject. This tendency towards degradation of the site is expressed mainly through the presence of Sida acuta (Malvaceae), Pupalia lappaceae (Amaranthaceae), Thalinum triangulare (Portulacaceae), Croton lobatus (Euphorbiaceae), Chromoleana odorata (Asteraceae), Hyptis suaveolens (Lamiaceae ), Panicum maximum and Andropogon gayanus (Poeceae).

With a view to restoring this site for ecotourism promotion, it is essential and urgent to reverse this deterioration trend rather before it reaches its irreversible level.

\section{DISCUSSION}

\subsection{Comparative study of the ecology of Nile crocodiles and those of the Ouèssè pond}

An endemic animal of the biotope, it is important and timely to give a brief overview of the ecology of Crocodylus niloticus or Nile crocodile.

\subsubsection{General ecology of the Nile crocodile}

\section{Range and habitat}

Of the class of reptiles, of the order of crocodilians and the family of crocodilids, the Crocodylus niloticusse meets in Africa, it is present along the Niger river and Lake Chad. There is also in Niger the narrow-nosed crocodile, farmed on private farms in Gaya. These are the species: Osteolamus tétraspis and Crocodylus cathaphractus (Lenoir and Megard, 2009). According to Koudèrin, Yaoïtcha, Adjé, Martin, Chanoine (2009), Lenoir, Megard, (2009), the Crocodylus niloticus frequents varied habitats ranging from swamps, large rivers passing by lakes and backwaters in some brackish water estuaries, in semi-tropical or tropical climate.

\section{Description}

The species can reach $6 \mathrm{~m}$ in length. Most of the individuals encountered frequently measure between 2 and 4 meters. Adult Nile crocodiles have a greenish gray color while juveniles approach an oliveish color. It has short but solid legs which end in five fingers for the forelegs and four for the hind legs). The hind legs are webbed which ensures the balance of swimming. The non-webbed forelegs are held against the body in water and are used only for walking on dry land. Its tail, slightly flattened, propels the crocodile underwater with slow lateral movements. A mobile membrane protects the eyes under water. The external ears, located behind the eyes, can be closed by a movable flap. The dermis is reinforced with bony plates called osteoderms, forming a dorsal shield (CREDI-ONG, 2009). The epidermis is made up of horny scales (scutes) which regenerate by periodic moulting.

\section{Food}


Crocodylus niloticus is a carnivore and a scavenger (Lenoir, Megard 2009). According to the same authors, it feeds on fish, amphibians, reptiles (turtles, lizards, snakes, sometimes baby crocodiles), birds, and mammals of all sizes. Very young crocodiles only eat insects, frogs and small fish.

Powerful jaws do not allow chewing lateral movements. As a result, the prey is ingested whole. The teeth all have the same conical shape and are housed in cells. The upper jaw carries between 28 and 32 teeth, the mandible between 30 and 40 . A hierarchy is noted for access to the meal: the oldest feed first and the others follow (CREDI-ONG, 2009).

\section{Manners}

Crocodylus niloticus is an amphibious animal. He lives in groups of adults and immatures of both sexes. The hierarchy is exercised in a variable way. It is practically nil for food: the strong and the weak eat simultaneously, on the other hand it is maximum during the reproduction period: the dominant males drive the others away from their territory and confront each other by intimidating postures (Lenoir, Mégard and CREDI ONG, 2009). The crocodile is a so-called "cold-blooded" animal, the temperature of its body depends on the external environment. It is exposed to the sun in the morning and evening when the outside temperature is low, and takes refuge in the water during the mid-day heat wave. It needs between $27^{\circ}$ and $35^{\circ}$ to move easily, to digest. To fight against the heat on the ground, the crocodile opens its mouth to cool it because, it does not sweat. The bellowing crocodile whispers, whistling more or less loudly depending on what it wants to express. In the event of great drought, when the water points are dry, it takes refuge in a burrow which it digs in the banks. It can thus survive for several weeks. If the drought persists, it dies (Lenoir, Mégard, 2009).

\section{Reproduction}

The maturity of the crocodile is reached around six (6) years. Once a year, the dominant males mate. This coupling is aquatic. It is preceded by slow preliminaries. The female lays her eggs in a hole she digs in the sand. Each clutch is composed of 25 to 95 eggs. The eggs incubate under the supervision of their mother for 3 months. As soon as they are ready to go out, the little ones squeal. At this signal, the mother releases them from the sand so that they can pierce their shell. With great delicacy, she carries all of her young in her mouth to the river. Early observers believed that crocodiles ate their newborns and for years it was claimed that males devour the offspring of females. In fact, it is very rare for a crocodile to kill these young ones. The male is generally as gentle as the female towards her offspring. The female takes care of the young for several months. They get into the habit of clumping on his back because ultimately it is the best shelter.

However, few of them will survive the predators and the death rate after the first year is estimated at around $90 \%$, which is justified by the chain system.

\subsubsection{Ecology of crocodiles from the Ouèssè Savalou pond}


Vol. 5, No. 02; 2020

ISSN: $2456-8643$

\section{Origin}

The origin of the crocodiles in the Ouèssè pond is not obvious and after various investigations, two hypotheses are possible. The first is linked to popular beliefs and supposes that the crocodiles spontaneously arrived on the site of the deity which saved the ancestors of the locality from the shortage of water. Their role was to protect the divinity and to translate its needs to the believing populations of this one. The second hypothesis in a more scientific logic is based on the hydrological regime of the environment. In the rainy season, the ponds are connected to the local hydrographic network by a small temporary stream. Crocodiles, like the populations of fish, would have gone up the stream to join the ponds. At the end of the rainy season, the stream dries up and the crocodiles are trapped, forced to stay in the ponds which they never dry out completely.

\section{Distribution area}

Crocodiles are present on the two main ponds: Todjitché and Than. Their migration downstream from the watershed during the rainy season is reported by residents. Another caiman pond was reported a few kilometers from the site, in the locality of Zounguèmè still in the commune of Savalou (field work, 2018).

\section{Abundance}

Analysis of the data collected on crocodiles allows us to affirm that the populations are mainly made up of young people. Only three crocodiles over a meter in length were seen.

The Ouèssè ponds are then probably breeding grounds for crocodiles in the watershed.

\section{Description}

The general morphology of Ouèssè crocodiles is consistent with that described above. However, out of the twenty crocodile specimens observed, none exceeded two meters in length.

\section{Food}

According to, Koudèrin, Yaoïtcha, Adjé, Martin, Chanoine (2009), the Ouèssè pools are full of frogs, crabs and in the case of the Todjiche fish pond. These animals represent as many potential prey for small Nile crocodiles. We also saw squirrels and birds drinking in the ponds in the early morning. These could very well occasionally be prey for medium-sized crocodiles. The contrast at the end of the collection is that, admittedly, the Ouèssè crocodiles are carnivores yes but, scavenging, difficult to confirm since all the tests invalidated the thesis. The chickens thrown in prey in the ponds left without being devoured by the crocodiles, a dead dog was thrown into the pond but despite the presence of the animals, two weeks later, the decomposing dog was removed. This certainly indicates the sacred character of the Ouèssè pond. Despite its designation of "man-eater", the Ouèssè crocodiles coexist peacefully in the pond since, grandchildren and old people of the local population go to the pond to get water without being attacked by crocodiles. 


\section{Manners}

According to the field results, the Ouèssè crocodiles seem to be more active at night. During the day they stay at the bottom of the burrows dug in the sides of the ponds. We counted a total of three main burrows on the Todjitché pool and two on the Than pool.

However, only two burrows were used at the time of the study for pool 1 and only one for pool 2. These burrows vary in depth from $85 \mathrm{~cm}$ to more than $2 \mathrm{~m}$ in depth. We were given the opportunity to see that juvenile crocodiles are much less fierce than their elders. They are therefore much more frequent and easy to observe or even to capture. During the flood season, burrows are flooded with water and their exploitation becomes difficult for crocodiles which should during this period remain almost all the time in open water. Drying areas are being developed to allow the animals to dry easily during the high water period and mid-day to facilitate their observation by the many tourists who go there. (Fieldwork, 2018

\section{Reproduction}

All indications are that the juvenile crocodiles observed on ponds 1 and 2 are believed to have come from recent local breeding. Thanks to the local populations, a small post-hatching crocodile nest was observed. This one was about a hundred meters from the "Than" pond, in a cultivated field. The small number of shells still present on the site suggests that it was a small lay of ten eggs. Based on the observation that the hatching of these eggs took place in April, we can estimate the spawning period of Ouèssè crocodiles around the months of December to January when we know that the brooding lasts 4 to 5 months.

\section{CONCLUSION}

In view of all of the above, it should be noted that the Ouèssè crocodile pond is a potential ecotourism site in the municipality of Savalou. The harmonious combination of natural resources and traditional beliefs is quite strong and deserves special attention.

To be more effective, the crocodile conservation and enhancement strategy must integrate the following points:

Support and revalorization of traditional cults and their dignitaries, then of deities relating to crocodiles;

The taking into account of data relating to the reproduction and feeding of Ouèssè crocodiles in the choice of facilities;

Sensitization of local populations to avoid as much as possible the permanent disturbance of the tranquility of crocodiles;

Improvement of the conditions for observing crocodiles to increase their ecotourism interest;

Monitoring or ecological monitoring of the pond must be done periodically in order to assess the impact of the developments on the dynamics of the inventoried biological resources. 
Vol. 5, No. 02; 2020

ISSN: $2456-8643$

\section{REFERENCES}

1- BUCKLAND S. T., ANDERSON D. R., BURNHAM K. P., LAAKE J. L., 1993. Distance sampling: Estimating of abundance of biological populations. London, England, Chapman and Hall, $448 \mathrm{p}$.

2- Municipality of Savalou, 2009, Tourism development strategy of the municipality of Savalou, 68 pages.

3- de SOUZA S, 1988, Flore du Bénin tome 3, 424 pages.

4- IUCN, 2007, Proceedings of the 1st Congress of West Africa on crocodiles "Breeding and conservation of crocodiles" Tapoa, W Regional Park of Niger, 140 pages.

5- KOUDERIN M.; YAOITCHA A.; ADJE B.; MARTIN D .; CHANOINE R., 2009, Ecotourism and educational development of the Ouèssè crocodile pond. Study report, CREDI ONG, 36 pages.

6- LENOIR F .; MEGARD J P., 2009, Nile Crocodile (Crocodylus niloticus). SECAS- Paris, 02 pages. http: // secas.org.

7- MATHOT Luc, 2003, Study on the diversity and distribution of fauna in Ufa 10-030. Inventory report, Nature Plus, Project Network of Partnerships for Sustainable Forest Management in Central Africa, Société R. Pallisco, 19 p.

8- MATHOT Luc, Jean-Louis DOUCET, 2006, Wildlife inventory method for zoning concessions in tropical forests, Bois et forêt des tropiques, $\mathrm{n}^{\circ} 287,59$ pages. 